\title{
Corrigendum
}

\section{Hydrotalcite Can Prevent the Damaging Effects of Helicobacter Pylori on Gastric Epithelial Cells-CORRIGENDUM}

Yanyan Shi, Yanlei Guo, Ting Zhang and Shigang Ding

Doi: doi.org/10.1017/S1431927618000314, Published by Cambridge University Press, 28 June 2018

In the original publication, the author names were incorrect. All author names have since been corrected in the original published article.

\section{Reference}

Shi Y, Guo Y, Zhang T, et al. (2018). Hydrotalcite can prevent the damage effect of helicobacter pylori on gastric epithelial cells. Microsc Microanal 24, 277-283. 